\title{
Eco-friendly route for dyeing of cotton fabric using three organic mordants in reactive dyes
}

Coloranții textile și agenții de fixare care sunt utilizați în procesul de vopsire contribuie în mare măsură la poluarea mediului. În studiul de față, trei tipuri diferite de mordanți organici (citrat de sodiu, acetat de amoniu și acetat de potasiu) sunt utilizați la vopsirea prin epuizare, ca mordanți. Efectul concentrațiilor de mordanți este studiat pe baza proprietăților de rezistență a culorii (modificarea culorii, rezistența la frecare și rezistența la lumină) a bumbacului vopsit cu coloranți reactivi utilizând acești mordanți organici. Compararea acestor mordanți cu agentul de fixare convențional (NaCl) este, de asemenea, studiată pentru a evalua diferența dintre proprietățile de rezistență a culorii sărurilor convenționale și organice utilizate în acest studiu. S-a constatat că proprietățile de rezistență a culorii sărurilor convenționale și organice sunt comparabile, precum și încazul citratului de sodiu. În mod similar, intensitatea culorii țesăturii după vopsirea cu săruri organice și anorganice a fost măsurată utilizând Datacolor. Rezultatele au confirmat că valorile mai ridicate ale K/S sunt obținute pentru sărurile organice prin utilizarea unei concentrații mai scăzute de sare organic în comparație cu sarea convențională. Scăderea totalului solidelor dizolvate (TDS) ale efluenților colorați se situează între 6\% și $29 \%$ pentru trei săruri organice în comparație cu sarea convențională.

Cuvinte-cheie: coloranți reactivi, proprietăți de rezistență a culorii, mordanți organici, țesătură din bumbac, totalul solidelor dizolvate

\section{Eco-friendly route for dyeing of cotton fabric using three organic mordants in reactive dyes}

The textile dyes and fixing agents that used in dyeing process are major contributor to environmental pollution. In the present study, three different organic mordants (Sodium Citrate, Ammonium Acetate, and Potassium Acetate) are used in exhaust dyeing as mordants. Effect of mordant concentrations is studied on fastness properties (color change, rubbing fastness \& light fastness) of cotton dyed with reactive dyes using these organic mordants. Comparison of these mordants with conventional fixing agent $(\mathrm{NaCl})$ is also studied in order to evaluate the difference between fastness properties of conventional and organic salts used in this study. We found that the color fastness properties of conventional and organic salts are comparable, better in case of sodium citrate. Similarly color depth on fabric after dyeing with organic as well as inorganic salts is measured using data color. Results confirm that higher values of K/S are obtained for organic salts by using lower organic salt concentration compared to conventional salt. Reduction in total dissolved solids (TDS) of dye effluents is obtained from $6 \%$ to $29 \%$ for three organic salts as compared to conventional salt.

Keywords: reactive dyes, fastness properties, organic mordants, cotton fabric, total dissolved solids

\section{INTRODUCTION}

Dyeing and finishing processes are integral part of textile industry. Variety of methods is being used in textile industry to improve the dyeing process [1]. Exhaust dyeing is one of all these processes used in textile dyeing. It has good fatness properties due to dye fibre chemical bonding as compare to other dyeing processes. Due to the presence of xenobiotic compounds in textile waste of this process, it contributes a lot in creating environmental pollution [2]. Textile effluents usually contain alkalis, organic acids, organic dyes, finishing agents and non-biodegradable inorganic salts $[3,4]$. These textile waste materials are harmful for aquatic life as well as it is responsible for many diseases in humans [5]. For treatment of these toxic compounds many methods have been developed which include adsorption, oxidation, anaerobic decolourization, catalysis, ion exchange, membrane filtration, flocculation and ozonation [6-8]. All these methods have certain drawbacks, they can reduce the pollution but they are expensive. Another major issue is the disposal of solid waste produced during such treatments [9]. One obvious solution of this problem could be the use of better chemicals and improve the processing technology in order to reduce pollution problems.

Reactive dyes are mostly used in textile industry to produce bright colours. These reactive dyes also impart fastness properties to the dyed fabrics due to the strong covalent bonding under alkaline conditions between natural fibre and dye [10]. It is well known that reactive dyes have low degree of fixation on the textile fabric [11]. For any type of dying process, usually surfactants, inorganic salts and alkalis are required during dyeing process in order to fix the dye into fibre under suitable alkaline conditions [12-13]. 
These salts and alkalis, after dyeing process are drained along with effluents. Due to incorporation of salts and alkalis in the waste effluents, value of dissolved solids increases into the effluent in the form of Total Dissolved Solids (TDS) which also produces environmental pollution [14-15]. Improvement in dyeing techniques, machinery and use of more improved structural dyes has helped in reduction of organic salts and ultimately TDS in the effluents [16-19].

Use of organic salts instead of conventional inorganic salt could reduce the pollution problem because the removal and degradation of organic salts is easier. In the present work an attempt has been made to replace the conventional inorganic salts with organic salts. Effect of using reduced concentration of organic salts on the dyeing properties, colour depth and $\mathrm{K} / \mathrm{S}$ values has been studied. It has been observed that reduced concentration of organic salts under the same dyeing conditions not only helps to decrease the TDS in textile effluents, but also improves colour depth.

\section{EXPERIMENTAL}

\section{Chemicals and reagents}

Cotton twill fabric having $200 \mathrm{~g} / \mathrm{m}^{2}, 160$ ends/inch and 60 picks/inch was used in this study. Reactive dyes C.I. Reactive Blue 250, C.I. Reactive Red 195, C.I. Reactive Yellow 145 \& C.I. Reactive Black 5 were used. Organic mordants used in this study were mono sodium citrate, ammonium acetate and potassium acetate supplied by Sigma Aldrich. All these chemicals were of analytical grade and were used without any further pre-treatment.

\section{Dyeing procedure}

Commercially scoured and bleached Twill fabric was used for exhaust dyeing. IR dyer (D400IR) was used to dyecotton fabric. $0.4 \%$ aqueous solution of each dye was prepared and then fed into the IR dyer along-with fabric. Liquor ratio (1:10) was adjusted according to fabric weight. $2 \mathrm{~g}$ commercially available salt of sodium chloride and $3 \mathrm{~g}$ sodium bicarbonate was added into the container. Similarly, $2 \mathrm{~g}$ of each organic salt \& $3 \mathrm{~g}$ sodium bicarbonate was separately weighed and feed into already labeled separate containers of IR Dyer having dye solution and fabric. The details of the dyeing conditions arementioned in table 1.

Table 1

\begin{tabular}{|c|c|}
\hline Dying Process & Exhaust dying \\
\hline Dyeing Temperature & $70^{\circ} \mathrm{C}$ \\
\hline Dyeing Time & 30 minutes \\
\hline Baths rotational speed & 40 rpm \\
\hline Dye Depth Shade & $2 \%$ shade \\
\hline
\end{tabular}

At the completion of dyeing procedure, contents of IR dyer were drain out leaving dyed fabric. Fabric was washed and rinsed with hot water $\left(95^{\circ} \mathrm{C}\right)$ and then with water at room temperature till desorption of dye [20].

Samples were removed from IR Dyeing machine D400IR, washed, dried and conditioned then, evaluated for fastness properties (fastness to light on weathero meter Ci 3000, crocking on AATCC Crockmeter, and laundering on Washtec-p Launder o meter) by using standard testing methods.

The dyeing parameters such as the effect of concentration of organic salts on the dyeing properties, color depth and K/S values were also studied using similar procedure.

\section{RESULTS AND DISCUSSION}

\section{Evaluation of fastness properties}

Fastness properties of dye are considered as an important parameter in dying process. Fasteners are basically binding agents which bind the reactive dyes to the cellulose fibers and improve the binding strength during wet treatments. Fastening agents improve the production rate by reducing the washing baths and process time. We also studied the fastening properties of four dyes using organic mordants. For comparison, the effect of traditional inorganic salt $(\mathrm{NaCl})$ is also applied to the same dyes under similar conditions. We applied different standard methods to evaluate the fastness properties including (BO5 for fastness to light, AATCC 8 for fastness to dry and wet crocking, AATCC 61 for fastness to laundering). Results of fastness properties using conventional as well as organic salt for all the dyes are shown in table 2.

Results confirm that all organic salts show better fastness properties for all the methods compared to conventional salt i.e. $\mathrm{NaCl}$. Different types of cotton fibers were also tested to further justify the hypothesis but these mordants show better results in all types of fibers. Better colour change has also been observed in all dyes by applying organic mordants. This may be attributed to the better association of citrate and acetate groups to the cotton fibers. Among organic salts, sodium citrate showed better fastness properties than ammonium acetate and potassium acetate. These results prove that organic salts can be used as potential replacements for conventional inorganic mordants due to their better fastening properties and eco-friendly nature. This leads to the decrease in TDS in the effluent water normally caused by the use of sodium chloride. With further optimization these mordants could be applied at industrial scale.

\section{Optimization of salt concentration vs color yield}

With increasing salt concentration, dye levelness improves and resultant color yield [21-22]. Initially we optimized the effect of concentration of inorganic salt on the color yield of the fabric using $2 \%$ dye solution and varying concentrations of inorganic salt from $1 \%$ to $5 \%$ using liquor ratio of $(1: 10)$. Results show that for C.I Reactive Blue 250 using 5\% Sodium Chloride $(\mathrm{NaCl})$, maximum value of color yield is obtained. 


\begin{tabular}{|c|c|c|c|c|c|c|c|c|c|c|c|}
\hline \multirow{3}{*}{$\begin{array}{c}\text { Dye } \\
20 \mathrm{gm} / \mathrm{l}\end{array}$} & \multirow[t]{3}{*}{ Mordants } & \multicolumn{7}{|c|}{$\begin{array}{l}\text { Colour fastness to accelerated laundering } \\
\text { AATCC } 61\end{array}$} & \multicolumn{2}{|c|}{$\begin{array}{l}\text { Color fastness } \\
\text { to crocking } \\
\text { (AATCC 8) }\end{array}$} & \multirow{3}{*}{$\begin{array}{c}\text { CF to ligh } \\
\text { (ISO } \\
\text { 105BO2) }\end{array}$} \\
\hline & & \multicolumn{6}{|c|}{ Staining } & \multirow{2}{*}{$\begin{array}{c}\text { Col } \\
\text { change }\end{array}$} & \multirow{2}{*}{ Dry } & \multirow{2}{*}{ Wet } & \\
\hline & & Ace & Co & Ny & Po & Acr & Wo & & & & \\
\hline \multirow{4}{*}{$\begin{array}{c}\text { C.I } \\
\text { Reactive } \\
\text { Blue } 250\end{array}$} & Sodium Chloride & $4-5$ & $4-5$ & 4 & $4-5$ & $4-5$ & $3-4$ & 4 & $4-5$ & 4 & $7-8$ \\
\hline & Potassium Acetate & $3-4$ & $3-4$ & $3-4$ & $4-5$ & $4-5$ & $3-4$ & 4 & $3-4$ & $3-4$ & $4-5$ \\
\hline & Ammonium Acetate & $4-5$ & $4-5$ & $4-5$ & $4-5$ & $4-5$ & $4-5$ & $3-4$ & $4-5$ & $3-4$ & 5 \\
\hline & Sodium Citrate & $4-5$ & $4-5$ & $4-5$ & $4-5$ & $4-5$ & 4 & $4-5$ & $4-5$ & $4-5$ & 8 \\
\hline \multirow{4}{*}{$\begin{array}{c}\text { C.I } \\
\text { Reactive } \\
\text { Red } 195\end{array}$} & Sodium Chloride & $4-5$ & $4-5$ & $4-5$ & $4-5$ & $4-5$ & $4-5$ & $4-5$ & $4-5$ & $4-5$ & 8 \\
\hline & Potassium Acetate & $4-5$ & 4 & $4-5$ & $4-5$ & $4-5$ & 4 & 4 & $3-4$ & $4-5$ & $5-6$ \\
\hline & Ammonium Acetate & $4-5$ & $4-5$ & $4-5$ & $4-5$ & $4-5$ & $4-5$ & $3-4$ & $4-5$ & 4 & $5-6$ \\
\hline & Sodium Citrate & $4-5$ & $4-5$ & $4-5$ & $4-5$ & $4-5$ & $4-5$ & $4-5$ & $4-5$ & $4-5$ & $7-8$ \\
\hline \multirow{4}{*}{$\begin{array}{c}\text { C.I } \\
\text { Reactive } \\
\text { Yellow } \\
145\end{array}$} & Sodium Chloride & $4-5$ & $4-5$ & 4 & $4-5$ & $4-5$ & $4-5$ & 4 & $4-5$ & $3-4$ & $7-8$ \\
\hline & Potassium Acetate & $4-5$ & $3-4$ & $4-5$ & $4-5$ & $4-5$ & 4 & $3-4$ & $4-5$ & $4-5$ & $6-7$ \\
\hline & Ammonium Acetate & $4-5$ & 4 & 4 & $4-5$ & $4-5$ & $4-5$ & $4-5$ & $4-5$ & $3-4$ & $5-6$ \\
\hline & Sodium Citrate & $4-5$ & 4 & $4-5$ & $4-5$ & $4-5$ & 4 & $4-5$ & $4-5$ & $4-5$ & 8 \\
\hline \multirow{4}{*}{$\begin{array}{c}\text { C.I } \\
\text { Reactive } \\
\text { Black } 5\end{array}$} & Sodium Chloride & $4-5$ & 5 & 4 & $4-5$ & $4-5$ & $4-5$ & $4-5$ & $4-5$ & 4 & $7-8$ \\
\hline & Potassium Acetate & $4-5$ & $4-5$ & $4-5$ & $4-5$ & $4-5$ & $4-5$ & 4 & $4-5$ & $3-4$ & $6-7$ \\
\hline & Ammonium Acetate & $4-5$ & $4-5$ & $4-5$ & $4-5$ & $4-5$ & $4-5$ & $3-4$ & 4 & 4 & $5-6$ \\
\hline & Sodium Citrate & $4-5$ & 5 & $4-5$ & $4-5$ & $4-5$ & 4 & $4-5$ & $4-5$ & $4-5$ & 6 \\
\hline
\end{tabular}

Similarly changing the alkali concentration also affected the color yield. Changing the concentration from $0.5 \%$ to $3 \%$, using $2 \%$ solution of C.I Reactive Blue 250 under same dyeing conditions as mentioned above. Results show that maximum color yield is obtained at $1.5 \%$ alkali solution, using $5 \%$. Effect of salt concentration on color yield is shown in figure 1.

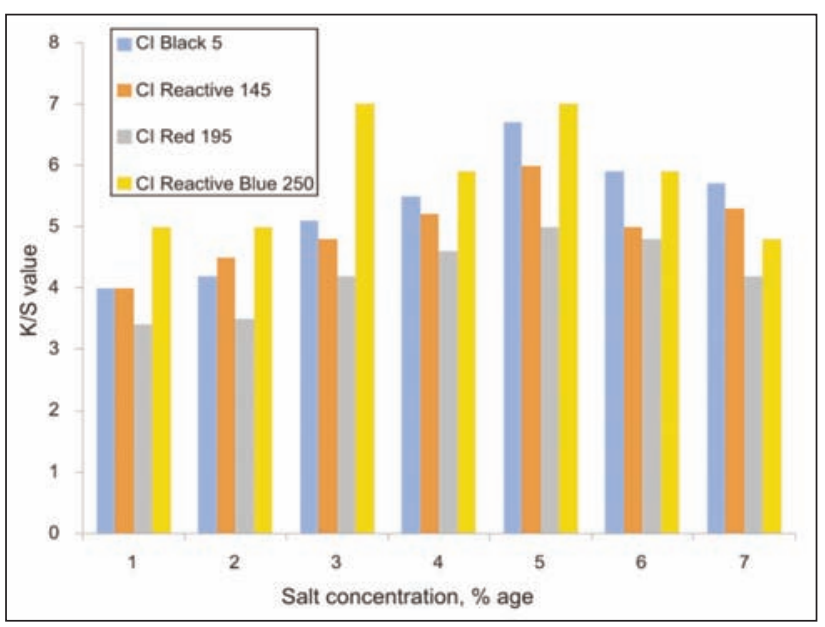

Fig. 1. Color yield vs salt concentration (\%)

Similarly, dyeing is performed using $2 \%$ reactive dyes, by taking each of $2 \%$ organic salts including potassium acetate, ammonium acetate and sodium citrate. Color strength for each dyed fabric is taken using data color (SF650X). Results show that greater values of color ratio (K/S) are obtained using lower concentration of organic salts for different reactive dyes compared to conventional inorganic salts which required higher concentration for fixation of dyes on fabric. This shows that inorganic salts are better substitute of inorganic salt. This lower concentration of organic mordants is also helpful in lowering of total dissolved solids in effluents of dyeing in textile industry. Results showing the effect of organic salt concentration on K/S value are shown in figure 2 .

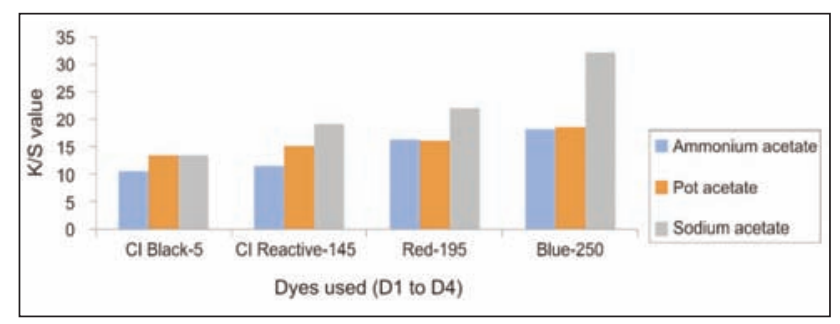

Fig. 2. Effect of organic salt concentration on $\mathrm{K} / \mathrm{S}$ value on cotton fabric using reactive dyes

\section{Effluent analysis}

Purpose of this study is to reduce the TDS of dye effluent by using alternative biodegradable electrolyte. Table 3 shows that the use of Sodium Citrate reduce nearly $17 \%-29 \%$ TDS of effluents for all dyes as compare to conventional inorganic salt Sodium Chloride. Similarly TDS of effluents was reduced $6 \%-20 \%$ by using organic salts Potassium Acetate and Ammonium Acetate. Reduction in TDS due to use of sodium citrate the lower level in total dissolved salt for all the dyes are because of the lower concentration of the sodium citrate for the better color fixation and better color yield. This gives better color yield for all the used dyes. It shows that in the effluent the unfixed dye ratios is reduced and make the Sodium Citrate an ecofriendlysalt for dyeing. Further, it provided significantly higher color yields for all dyes. The ratio of unfixed dye in the effluent remarkably reduced and a Sodium Citrate salt is environment friendly. 
Table 3

\begin{tabular}{|c|c|c|}
\hline $\begin{array}{l}\text { Dyes used } \\
(20 \mathrm{~g} / \mathrm{l})\end{array}$ & $\begin{array}{l}\text { Effluent samples } \\
\text { (diluted } 100 \text { times) }\end{array}$ & $\begin{array}{l}\text { TDS } \\
(\mathrm{mg} / \mathrm{l})\end{array}$ \\
\hline \multirow{4}{*}{$\begin{array}{l}\text { C.I Reactive } \\
\text { Blue } 250\end{array}$} & Sodium Citrate $(40 \mathrm{~g} / \mathrm{l})$ & 1010 \\
\hline & Potassium Acetate $(40 \mathrm{~g} / \mathrm{l})$ & 1145 \\
\hline & Ammonium Acetate & 1280 \\
\hline & $\begin{array}{l}\text { Sodium chloride }(50 \mathrm{~g} / \mathrm{l}) \\
\text { Sodium bicarbonate }(15 \mathrm{~g} / \mathrm{l})\end{array}$ & 1380 \\
\hline \multirow{4}{*}{$\begin{array}{l}\text { C.I Reactive } \\
\text { Red } 195\end{array}$} & Sodium Citrate $(40 \mathrm{~g} / \mathrm{l})$ & 990 \\
\hline & Potassium Acetate $(40 \mathrm{~g} / \mathrm{l})$ & 1110 \\
\hline & Ammonium Acetate & 1295 \\
\hline & $\begin{array}{l}\text { Sodium chloride }(50 \mathrm{~g} / \mathrm{l}) \\
\text { Sodium bicarbonate }(15 \mathrm{~g} / \mathrm{l})\end{array}$ & 1400 \\
\hline \multirow{4}{*}{$\begin{array}{l}\text { C.I Reactive } \\
\text { Yellow } 145\end{array}$} & Sodium Citrate $(40 \mathrm{~g} / \mathrm{l})$ & 1140 \\
\hline & Potassium Acetate $(40 \mathrm{~g} / \mathrm{l})$ & 1215 \\
\hline & Ammonium Acetate & 1250 \\
\hline & $\begin{array}{l}\text { Sodium chloride }(50 \mathrm{~g} / \mathrm{l}) \\
\text { Sodium bicarbonate }(15 \mathrm{~g} / \mathrm{l})\end{array}$ & 1390 \\
\hline \multirow{4}{*}{$\begin{array}{l}\text { C.I Reactive } \\
\text { Black } 5\end{array}$} & Sodium Citrate $(40 \mathrm{~g} / \mathrm{l})$ & 1130 \\
\hline & Potassium Acetate(40 g/l) & 1220 \\
\hline & Ammonium Acetate & 1325 \\
\hline & $\begin{array}{l}\text { Sodium chloride }(50 \mathrm{~g} / \mathrm{l}) \\
\text { Sodium bicarbonate }(15 \mathrm{~g} / \mathrm{l})\end{array}$ & 1420 \\
\hline
\end{tabular}

\section{CONCLUSION}

In this research, for the first time, we evaluated the effect of three organic salts on dying of cotton fabric using four reactive dyes. We studied the effect of organic mordants on different dying parameters such as fastness properties, color yield and K/S value. From the results, we can conclude that the organic salts including sodium citrate, potassium acetate and ammonium acetate show comparable fastness properties as obtained in case of using conventional salts. Out of these three salts sodium citrate show better fastness properties as compared to other salts. Furthermore, at lower concentration organic salts show higher $\mathrm{K} / \mathrm{S}$ values.

The use of these biodegradable salts during the dyeing process helps in decreasing TDS which is ultimately reduction in environmental pollution.

Effluents analysis shows that $6 \%-29 \%$ reduction in TSD is observed by using all three organic salts as mordants as compare to Conventional salt Sodium Chloride. So, we can predict that after further optimization these mordants could be potential replacement of traditional inorganic salts in textile industry.

\section{BIBLIOGRAPHY}

[1] Robinson, T., McMullan, G., Marchant R., and Nigam, P. Remediation of dyes in textile effluent: a critical review on current treatment technologies with a proposed alternative, In: Bioresource technology, Volume 77, Issue 3, pp. 247-255.

[2] Akhtar, S., Baig, S. F., Saif, S., Mahmood, A., and Ahmad, S. R. Five year carbon footprint of a textile industry: A podium to incorporate sustainability, In: Nature Environment and Pollution Technology, Volume16, Issue 1, pp. 125-132.

[3] Bilińska, L., Gmurek, M., and Ledakowicz, S. Comparison between industrial and simulated textile wastewater treatment by AOPs - Biodegradability, toxicity and cost assessment, In: Chemical Engineering Journal, Volume 306 , pp. 550-559.

[4] Zhang, W., Liu, W., Zhang, J., Zhao, H., Zhang, Y., Quan, X., and Jin, Y. Characterisation of acute toxicity, genotoxicity and oxidative stress posed by textile effluent on zebrafish, In: Journal of environmental sciences, Volume 24, pp. 2019-2027.

[5] Khan, S., and Malik, A. Environmental deterioration and human health: Natural and anthropogenic determinants, eds. A. Malik, E. Grohmann and R. Akhtar, In: Springer Netherlands, Dordrecht, 2014, pp. 55-71.

[6] Pekakis, P. A., Xekoukoulotakis, N. P., and Mantzavinos, D. Treatment of textile dyehouse wastewater by $\mathrm{TiO}_{2}$ photocatalysis, In: Water research, Volume 40, pp. 1276-1286.

[7] Sarayu, K., and Sandhya, S. Current technologies for biological treatment of textile wastewater - A review, In: Applied biochemistry and biotechnology, Volume 167, pp. 645-661.

[8] Husaain, D., Najam-ul-Haq, M., Saeed, A., Jabeen, F., Athar, M. and Naeem Ashiq, M. Synthesis of poly GMA/DVB and its application for the removal of Malachite Green from aqueous medium by adsorption process, In: Desalination and Water Treatment, Volume 53, pp. 2518-2528.

[9] Garg, V., Kaushik, P., and Dilbaghi, N. Vermiconversion of wastewater sludge from textile mill mixed with anaerobically digested biogas plant slurry employing Eiseniafoetida, In: Ecotoxicology and environmental safety, Volume 65, pp. 412-419.

[10] Khatri, A., Peerzada, M. H., Mohsin, M., and White, M. A review on developments in dyeing cotton fabrics with reactive dyes for reducing effluent pollution, In: Journal of Cleaner Production, Volume 87, pp. 50-57.

[11] Nabil, G. M., El-Mallah, N. M., and Mahmoud, M. E. Enhanced decolorization of reactive black 5 dye by active carbon sorbent-immobilized-cationic surfactant (AC-CS), In: Journal of industrial and engineering chemistry, Volume 20, pp. 994-1002. 
[12] Ferreira, A. M., Coutinho, J. A., Fernandes, A. M., and Freire, M. G. Complete removal of textile dyes from aqueous media using ionic-liquid-based aqueous two-phase systems, In: Separation and Purification Technology, Volume 128, pp. 58-66.

[13] Moreira, S., Milagres, A. M., and Mussatto, S. I. Reactive dyes and textile effluent decolorization by a mediator system of salt-tolerant laccase from Peniophoracinerea, In: Separation and Purification Technology, Volume 135, pp. 183-189.

[14] Vajnhandl, S., and Valh, J. V. The status of water reuse in European textile sector, In: Journal of environmental management, Volume 141, pp. 29-35.

[15] Balapure, K., Bhatt, N., and Madamwar, D. Mineralization of reactive azo dyes present in simulated textile waste water using down flow microaerophilic fixed film bioreactor, In: Bioresource technology, Volume 175, pp. 1-7.

[16] Kharat, $D$. Treatment of textile industry effluents: limitations and scope, In: Journal of Environmental Research and Development, 2015, Volume 9, p. 1210.

[17] Noroozi, B., and Sorial, G. A. Applicable models for multi-component adsorption of dyes: A review, In: Journal of Environmental Sciences, Volume 25, pp. 419-429.

[18] Kongahge, D., Foroughi, J., Gambhir, S., Spinks, G. M., and Wallace, G. G. Fabrication of a graphene coated nonwoven textile for industrial applications, In: RSC Advances, Volume 6, pp. 73203-73209.

[19] Dasgupta, J., Sikder, J., Chakraborty, S., Curcio, S., and Drioli, E. Remediation of textile effluents by membrane based treatment techniques: A state of the art review, In: Journal of environmental management, Volume 147, pp. 55-72.

[20] Li, Y., Ren, J., Chen, S., Fan, F., Shen, Q., and Wang, C. Cationic superfine pigment dyeing for wool using exhaust process by $\mathrm{pH}$ adjustment, In: Fibers and Polymers, Volume 16, pp. 67-72.

[21] Haji, A. and Qavamnia, S. S. Response surface methodology optimized dyeing of wool with cumin seeds extract improved with plasma treatment, In: Fibers and Polymers, Volume 16, pp. 46-53.

[22] Javaid Mughal, M., Saeed, R., Naeem, M., Aleem Ahmed, M., Yasmien, A., Siddiqui, Q., and Iqbal, M. Dye fixation and decolourization of vinyl sulphone reactive dyes by using dicyanidiamide fixer in the presence of ferric chloride, In: Journal of Saudi Chemical Society, Volume 17, pp. 23-28.

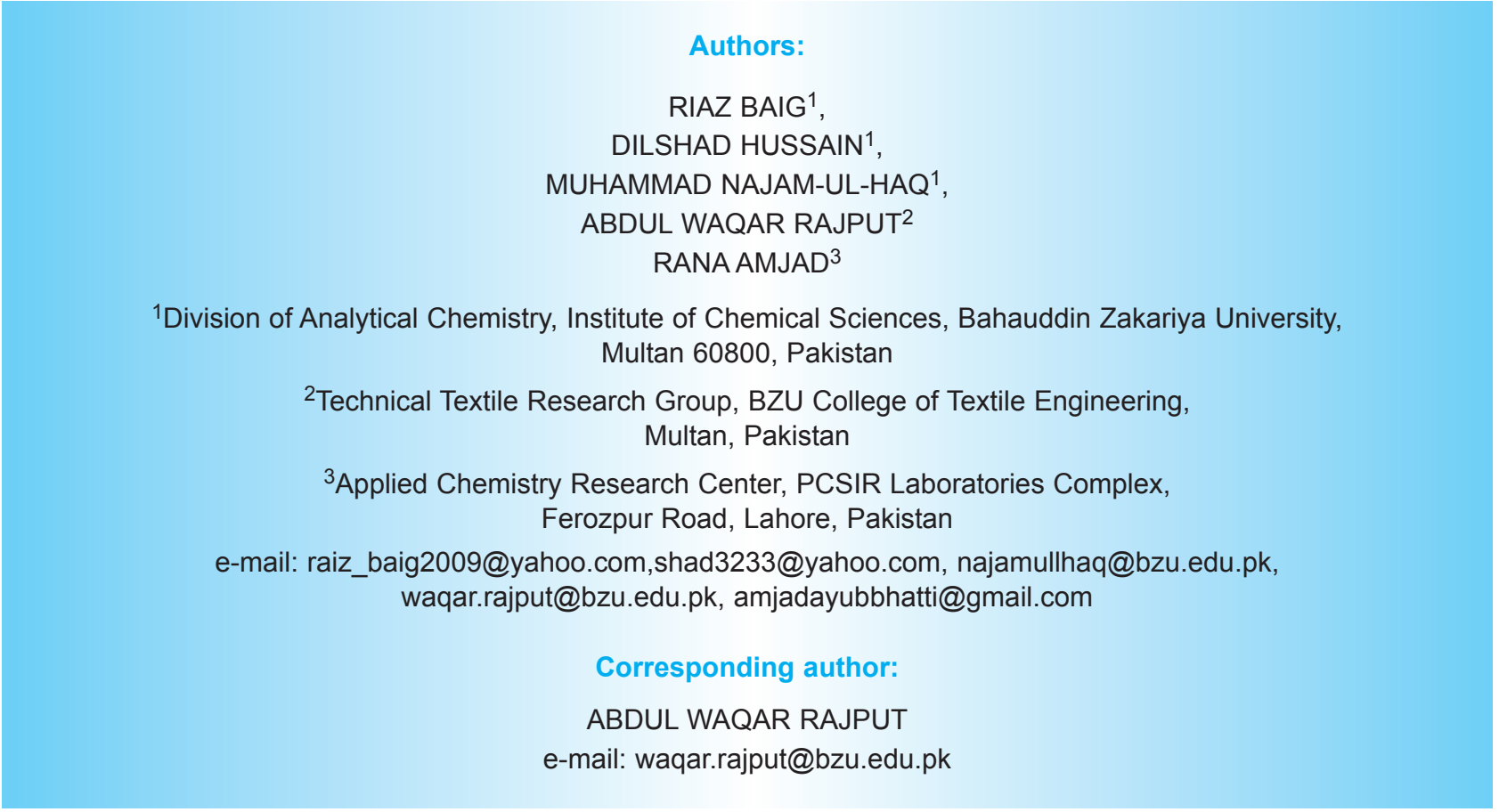

